\title{
Literature review on industry commercialization and transfer of technology 4.0
}

\section{Revisión de literatura en comercialización y transferencia de tecnología en la industria 4.0}

\author{
VILLAFAÑA-DÍAZ, Luis $\dagger^{*} *$ \& LEZAMA-DE LA ROSA, Miguel \\ Universidad Popular Autónoma del Estado de Puebla, México. \\ ID $1^{\text {st }}$ Author: Luis, Villafaña-Díaz / ORC ID: 0000-0002-4130-9595, CVU CONACYT ID: 609476 \\ ID $1^{\text {st }}$ Coauthor: Miguel, Lezama-de la Rosa / ORC ID: 0000-0003-2019-4271, CVU CONACYT ID: 440669
}

DOI: $10.35429 / J T P .2020 .18 .6 .1 .9$

Received July 15, 2020; Accepted December 21, 2020

\begin{abstract}
The bonding between searching and technological development strengthens commercial opportunities in 4th industrial revolution. This research analyzed main scientific contributions, published about commercialization and transfer of technology on 4.0 industry environment. The study was applied with 52 articles analyzed, which 30 of them objectively complied the study field from 2015 to 2020, an empiric methodology was applied, which allowed the theoretical construction, being the intellectual property the main commercial armor tool concerning patent management. Inside findings it was discovered a need of new strategies development to strengthen and accelerate the commercialization and transfer processes of technology, due to industry features 4.0, which has accelerated changes in most of the sectors, improving processes and information optimization, generating opportunities in international markets. Because of that the knowledge achieved in technological innovation can boost competitiveness besides income generation for organizations, but it must reach the commercialization and transfer stage, which has been achieved through the patent of the invention. According to the patent office registration, Mexico has one of the lowest levels compared with the main world economies. It is recommended to study more about this topic due to the scarce information in this field of study.
\end{abstract}

Technological Licensing, Intellectual Property, 4.0 industry

\begin{abstract}
Resumen
La vinculación entre investigación y desarrollo tecnológico fortalecen las oportunidades comerciales en la cuarta revolución industrial. Esta investigación analizó las principales contribuciones científicas, publicadas sobre la comercialización y transferencia de tecnología en el entorno de la industria 4.0. El estudio se realizó con el análisis de 52 artículos los cuales 30 cumplieron objetivamente el campo de estudio en el periodo del año 2015 al 2020, aplicando una metodología empírica la cual permitió la construcción teórica destacando el uso de la propiedad intelectual como principal herramienta de blindaje comercial en la gestión de patentes. Dentro de los hallazgos se encontró la necesidad del desarrollo de nuevas estrategias para fortalecer, así como acelerar los procesos de comercialización y transferencia de tecnología, debido a las características de la industria 4.0, la cual ha acelerado cambios en la mayoría de los sectores, mejorando la optimización de procesos e información, generando oportunidades en los mercados internacionales. Por tal motivo la generación de conocimiento reflejada en innovación tecnológica, puede impulsar la competitividad además de la generación de ingresos para las organizaciones pero debe alcanzar la etapa de la comercialización y transferencia, que se ha logrado a través de patentar la invención.
\end{abstract}

Licenciamiento tecnológico, Propiedad intelectual, Industria 4.0

Citation: VILLAFAÑA-DÍAZ, Luis \& LEZAMA-DE LA ROSA, Miguel. Literature review on industry commercialization and transfer of technology 4.0. Journal of Technological Prototypes. 2020. 6-18: 1-9.

\footnotetext{
* Correspondence to Author (email: luisgerardo.villafana@upaep.edu.mx)

$\uparrow$ Researcher contributing first author
} 


\section{Introduction}

There is a gap between technological. development and technology commercialization, due to the product buying purpose is mainly influenced by its perceived value. Success depends on the importance of processes of markets investment, as well as the proportionally commercialization to technological development, since models such as technology life cycle are found, where factors as losing a patent or intellectual property can directly influence on make shorter the life of products and technology.

Considering the global ambit, countries have to take in mind that digital world access opens opportunities for a sustained prosperity, so it must be considered a strategical development that aims in its implementation the unemployment reduction, inequality, and poverty eradication. In this sense, digital economy is quickly impacting to global economy causing big changes and growth, influencing on the commercial exchange of products and services as well as their related activities OCDE (2015).

Digitalization is transforming value chains in different directions allowing the opening of new channels, which make possible adding more value, stretching towards structural changes that will affect directly and indirectly to companies, countries and their workers; impact level will depend on development level, the speed of digital preparation, policy adoption and national implementation, regional and international UNCTAD (2019).

In recent years, the 4.0 industry has caught searchers and businessmen attention, since it contemplates a wide market, spanning production processes, efficiency, data management, relationship with consumers, competitiveness as well as technological scaling and maturation. For Lalanda, Morand and Chollet (2017) 4.0 industry is based on the application of new production techniques, new materials and the wide use of new digital technologies.
The importance of accelerating the selling process of patents and implementing commercialization strategies and technology transfer within 4.0 industry environment, requires having competitive traits due to markets tendencies, where the creation of intelligent processes is characterized for the adaptation capacity and productive resources efficiency. Jasiulewicz, Saniuk \& Nowicki (2017).

In the new technological age, the responsibility from universities is not based only on formation anymore, but passing the acquired knowledge through applied searching for industry with economic and social impact. Nowadays the ecosystem is in an evolutionary process of technology boosted by the 4.0 industry, such as Hecklau, Galeitzke, Flachs and Kohl (2016) indicated, which has as a main goal the creation of a diversity of opportunities for industries, by means of automation and digitalization process integration.

Bonding strategies with the triple helix improve the commercialization and transfer of technology process, since public universities as well as investigation centers are financed by government, in order that these form professionals to investigation development in early stages of maturation as well as solutions validation. On the other hand, the private businesses are those ones that acquire technologies by means of licenses and exclusivity contracts to ease the escalation and the introduction of new inventions to the market. The technological performance refers to the absorption and application capacity with success in the organization of the licensed and commercialized technological packages.

The goal of this investigation is to analyze the main scientific contributions, published about the commercialization and transfer of technology topic in the 4.0 industry environment.

\section{Materials and methods}

Methods are very important in empirical studies and for theory construction; databases were used such as Ebsco, Conricyt, Thomson Reuters, Science Direct, Scopus and Web of Science. 
52 articles were analyzed, which 30 of them achieved objectively the field of study concerning commercialization and transfer of technology inside 4.0 industry. In the same way for the filtering of relevant data there were applied different Boolean combinations AND, $\mathrm{OR}$ and truncation *,? helping to obtain the specific information.

In this same order and direction, the searching was made from 2015 to 2020, with the next key word combination in Spanish: Transferencia de Tecnología, Comercialización Tecnológica, Licenciamiento Tecnológico, Industria 4.0, Comercio Internacional, Patentes de la industria 4.0, Digitalización Tecnológica. In the same way with the next key word combination in English: Technology Tension, Technology Marketing, Technology Licensing, Industry 4.0, International Trade, Industry 4.0 Patents, Technology Digitalization.

\section{Commercialization and transfer of technology}

Khadhraoui, Plaisent, Lakhal and Prosper (2016) carried out a research work about the factors that affect the transfer of technology development from university to company.

They mentioned that one of the most relevant factors that improve the processes of innovation is technology transfer from university to company. Nevertheless, the potential barriers in the commercialization process within universities are bureaucracy as well as politics, nonexistence incentives for researchers, applied research funds, low culture concerning protection of intellectual property, high costs related to escalation and verification of technology.

Savescu (2017) proposed the fundamental aspects of intellectual property in the transfer of technology process with the finality of decreasing the level of concentration of falsification, as well as the novelty elements piracy inside the creative processes. In his results it could be observed how companies' competitiveness increases by means of intellectual property management as a tool for technology transfer and economic development inside the European Union.
Hayter and Link (2018) showed how big high technology companies improve their market position through intellectual protection, as well as divulgation of developed knowledge through scientific publications (SP) as commercial armor strategy. The SP are a legal substitute to industrial property invalidity when uncertainty of obtaining the patent title is very high. They identified that in commercialization and transfer of technology process the patents as well as scientific articles are recognized as an important indicator in the early stage commercial activity.

Maresova, Stemberkova and Fadeyi (2019) made a research about management models and transfer of technology in universities, which guarantee the increase on success rate, since these represent a fundamental role in investigation to the development of tradable products. The research results were 22 transfer of technology models, from four approaches, internal strategies, management and investment, politics and business development; where main goals, proceedings, strengths and each one deficiencies are described. The study identified new technology transfer models within emergent economies, where highlights the INNOSPICE model, which nourish software technologies in market.

\section{Industry 4.0}

Philbeck and Davis (2018) commented that 4th industrial revolution concept (4IR) has been used as a synonym of 4.0 industry, an initiative born in Germany between 2011 and 2015 which is focused on the digital technology application to manufacturing, despite this terms describe different aspects they are related, being a very important component in the 4IR narrative focused in the relationship between digitalization, transformational organization, and the productivity improvement.

Mikulic and Stefanic (2018) mention that 4.0 industry represents technology development and use that alters industry traditional models. 
They pointed out the traits that marks the globalization, stablishing new challenges with the existent resources generating new concepts such as intelligent factories, cyberphysical systems, stuff Internet, and intelligent products, forcing companies to embrace the new technologies to achieve all consumers demands including high quality and added value. They presented an article identifying advantages, as well as disadvantages of technology implementation considering the human factor impact, identifying the relationship between 4.0 industry and the efficient management, the main idea is to connect all the elements to the value chain process in just one system, to achieve it successfully is necessary the human factor inclusion in all stages from design and technology implementation.

Kodama (2018) mentioned that innovations that 4th industrial revolution requires (4IR) will be characterized by the accumulation of innovations, as well as technology evolution instead of disruptive innovations, besides fusing lines between physical, digital, and biological areas. The Japanese government proposed the term 5.0 to make reference to the combination of social problems solving and the economic progress made by the 4.0 industry.

Magruk (2016) indicated that uncertainty in the 4th industrial revolution give birth to new potential fields of research, in his work he analyses the different opportunities and threats. The author identified that a technological limit exists within the concept used by companies. It was discovered that the actual challenge is technology commercialization, by consequence of the infrastructure that is not adapted to these technologies. The study considers that 4.0 industry has very complex systems that could never be completely understood due to the indetermination of the concept.

Nikolic, Ignjatic, Suzic, Stevanov and Rikalovic (2017) proposed a study about predictive systems for fabrication and commercialization in the 4.0 industry, which found that the pushing of technological predictive systems has a positive consequence in the loss of costs, improvement of production and material resources efficiency.
Industry 4.0 sustainable model through commercialization shows the hidden innovation value as well as competence in the market, proposed by Misyunay, Mayhurova and Zubkov (2018), it made an analysis of business models and the competitiveness level, in the big data, artificial intelligence, cyber systems and stuff Internet, such study work developed the creation of key indicators that affect the competitiveness and the technology commercialization, with financial impacts and market shares growing in the medium term.

Intelligent objects require a minimal human intervention to develop the auto management capacities. In Kauffman and Soares (2018) research, it was described the intellectual property (IP) opportunities as a commercialization strategy in the 4th industrial revolution. According to the study the IP is the intangible active that is fundamental in the 4.0 industry, due to the impact on the value chain in the hardware protection, software and the storage data processes; these could ascend to the $80 \%$ of a company value. The study also proposes de industrial secret as the best option to protect the innovations related to the 4.0 industry, due to this decreases the level of unfair competition, likewise in 2017 the success rate improved in $69 \%$ the litigation in the United States of America.

Dash, Farooq, Sankar and Sandhyavani, (2019) made an evidenced study about competence development in 4th industrial revolution and the stuff Internet, the authors mentioned that technological advances are marked by the acceleration of innovation and artificial intelligence estimating 30 thousand millions of devices in 2025. Data was obtained through a comparative of regulations, theoretical evidences and challenges in assimilation of new technological tendencies. It was obtained that new innovation politics in India are based on the digital empowerment by the adoption of emergent technologies, becoming the labor force more productive and efficient. 


\section{Commercialization and transfer of technology in the 4.0 industry}

The transfer of technology in the 4.0 industry bring closer to the small and medium companies to the efficiency and flexibility, the study made by Wank (2016) showed the opportunity to increase competitiveness from digitalization as well as the interconnection in the fabrication processes, making an analysis from optimization in industry and the value chain, which helped to link companies with the 4.0 industry technologies through new market opportunities.

Dong and Jong (2017) presented a study work about the determinant features in the marketing performance in high technological companies. It was found that these companies use the social capital as a collaboration network and bonding for the innovation growth in the technological performance. The study was crucial to identify the factors that influence the performance and adaptation improvement of technology in the process of commercialization or discharge.

Technology transfer and human capital in the 4.0 industry shows the acceleration in the digital process between the academy, company and government, is the case of the study published by da Silva, Kovaleski and Pagani (2018) in which the changes and perspectives of human processes inside the 4.0 industry are analyzed. The authors mentioned that the pillar of this model is the big data, autonomous robots, simulation, horizontal and vertical systems integration, Internet stuff, cybersecurity, cloud computing, additive manufacturing and augmented reality.

Jun, Park and Jang (2015) developed a technological assessment model based on the European international patent classification (IPC) H01S3/05 from a technology transfer of big data. They identified that usually the transfer of technology is made from universities to companies through licensing; by consequence they built the model from intellectual property protection, data mining, I+D planning, technological segments, as well as future descriptive statistics. It brought a model that strengthens the decision making in the decreasing of financial risk in technological investments.
Gbadegeshin, (2018) proposed a new slender marketing theoretical framework which has as a main objective the reduction of economic risks and the technical uncertainty for the commercialization of new services and products. It was obtained that due to the nature of digital technology the commercialization processes have to be validated fast through the technical analysis of market and influenced by the intellectual property. The digitalization fusion in physical products, digital services as well as biological spheres, improve the commercialization process by means of metadata sourcing, artificial intelligence and automation that make easier the information measurement bringing a competitive advantage. The study helps to the commercialization acceleration of high technologies by means of the minimal investment in technical and commercial validation inside health areas in Finland.

In this way, Hyunji, Sun and Won (2019) presented a study about the technological performance which is based on the $\mathrm{I}+\mathrm{D}$ performance in patents and selling increasing as well as reduction of costs. Likewise the commercialization performance was measured according to PYMES development capacity, identifying the success factors of high technology industries commercialization. It was obtained that technological development cost has an influence on the technical performance competitiveness, that is, as higher is the I+D cost greater is the commercialization capacity. An opportunity was identified in relation to the pymes performance in the Korean economic industry.

The acceleration in the commercialization and transfer of technology from the opened innovation approach, study proposed by Wahyudi, Rina and Retno (2019) showed a variable measurement in the commercialization of technology models performance developed in universities. The study helped to compare the efficiency in commercialization strategies, discharge and spin offs creation managed by universities. 
Kim, Sawng, \& Park, (2019) propose a validation model of the commercialization process of a 3 stage digital innovation, technology, product and market, where technology acceptation depends on the technological market potential as well as the consumer's perspective. The study identified that the most advanced countries focus on increasing the business competitiveness through open innovation, due to the intention on buying a new technology is significantly influenced by its perceived value, this is, the importance on demand of the digital technological market. For increasing the commercialization opportunities, it is wise to evaluate potential client needs and the market size.

In this manner Yeverino and Montoro (2019) made an investigation about the efficiency and the productivity of academic units in charge of technology transfer in Mexico. It was obtained that a strong heterogeneity in the institutions and searching centers between a limited productivity, license revenue, notifications of inventions, intellectual property expenses, as well as the transfer of technology offices experience, highlighting 40 years of retardation in this industry with respect to most competitive countries such as USA.

The interest in the development of searching work with technological basis within higher education institutions in Mexico has become bigger, with the objective of generating new knowledge to compete, as well as improving the national economic growth, Puerta, Marín and López (2017) developed an institutional framework to explain the determinant factors in activities that make easier the transfer of technology, such work identified the necessity of managing the intellectual property of universities by a transfer of technology office, to encourage to researchers and the academic staff, to protect the intellectual property developed, to strengthen linking activities with the business and governmental sector and to spread the technological projects with society. It highlights the importance of maximizing the success chances of technology commercialization through the triple helix model, which is based on the strategical linking between university, company and government.
Gathering OCDE data and indicators inside its database about technology and innovation, Mexico shows the following results about triad patent register, indicator referring to a registered patent in 3 patent offices: USA, Japan and the European Union.

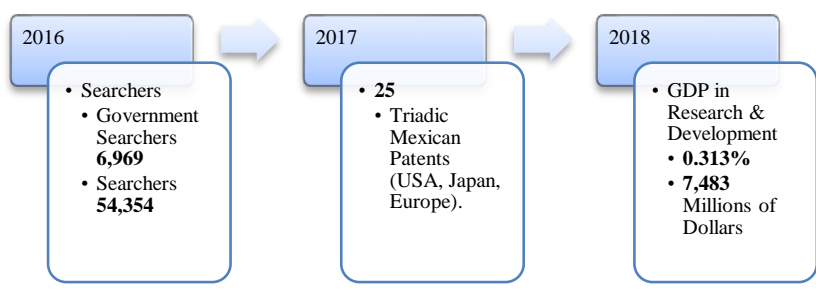

Figure 1 OCDE Mexico Indicators

Source: OCDE Innovation and Technology Indicators, Data 2020

Comparing Mexico with the G20 countries, in 2017 Mexico was in the 17th position with relation to the triadic patent registration as it is showed in the next chart.

G20 Mexico registred 25 triadic patents and occupied the 17 th place.

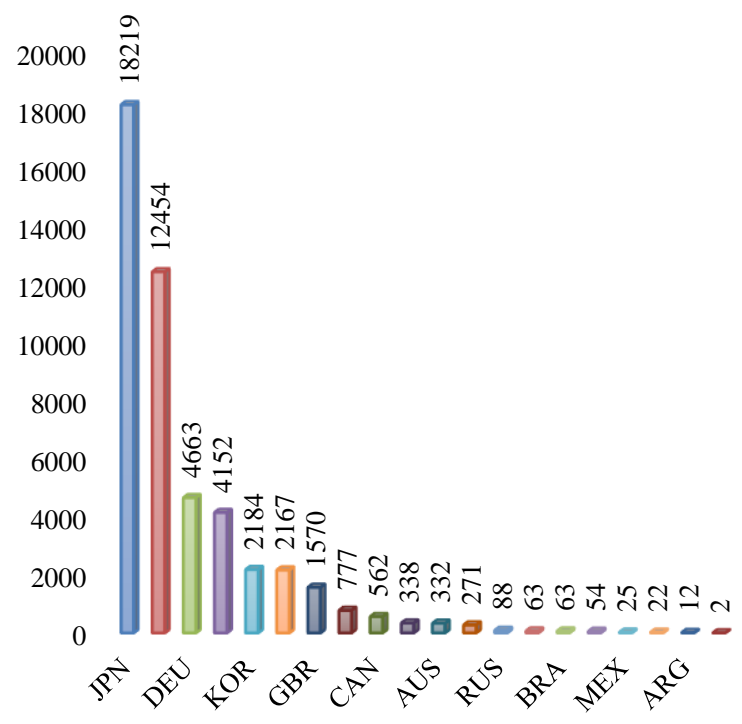

Graphic 1 OCDE indicators Triadic Patent Families Source: OCDE Innovation and Technology Indicators, Data 2020

According to the ENPECYT survey made by INEGI in collaboration with CONACYT, the perception in population over 18 , relating to inventions, discovery as well as technological development, shows a knowledge level in population mainly moderate, nevertheless the nullity perception is higher than good and very good perception. 


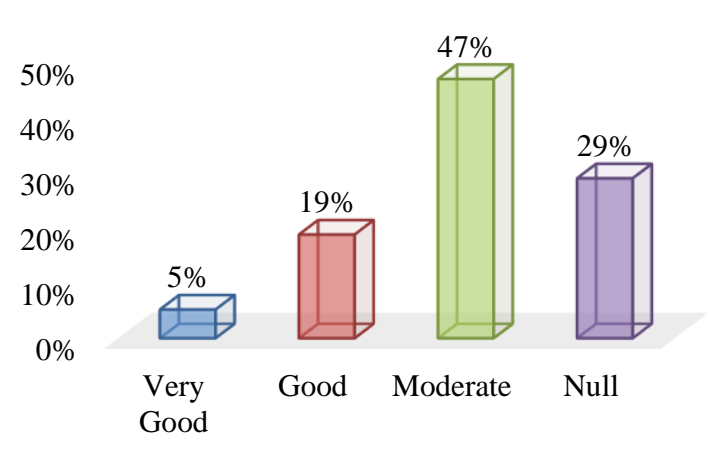

Graphic 2 Level of knowledge in Mexico concerning inventions and discoveries

Source: INEGI, CONACYT, (ENPECYT) 2017

In the next chart it is showed the contribution of all the papers relating to commercialization methodology and technology transfer.

\begin{tabular}{|c|c|c|c|}
\hline Authors & Study Work & Results & Methodology \\
\hline $\begin{array}{l}\text { Jun S., } \\
\text { Park S., } \\
\text { and Jang } \\
\text { D. (2015) }\end{array}$ & $\begin{array}{l}\text { Technological } \\
\text { assessment } \\
\text { model through } \\
\text { the } \\
\text { quantitative } \\
\text { analysis of } \\
\text { patents: a } \\
\text { transfer of } \\
\text { technology } \\
\text { case study in } \\
\text { Big Data } \\
\text { Marketing }\end{array}$ & $\begin{array}{l}\text { Transfer of } \\
\text { technology is } \\
\text { made from } \\
\text { universities to } \\
\text { companies } \\
\text { through } \\
\text { licensing }\end{array}$ & $\begin{array}{l}\text { Technological } \\
\text { assessment } \\
\text { model based } \\
\text { on the } \\
\text { international } \\
\text { classification } \\
\text { of European } \\
\text { patents IPC } \\
\text { H01S3/05 }\end{array}$ \\
\hline $\begin{array}{l}\text { Wank } \\
\text { (2016) }\end{array}$ & $\begin{array}{l}\text { To increase } \\
\text { competitivenes } \\
\mathrm{s} \text { from } \\
\text { digitalization } \\
\text { making } \\
\text { analysis from } \\
\text { industry and } \\
\text { chain value } \\
\text { optimization }\end{array}$ & $\begin{array}{l}\text { It helped } \\
\text { linking } \\
\text { companies } \\
\text { with industry } \\
4.0 \\
\text { technologies } \\
\text { though new } \\
\text { market } \\
\text { opportunities }\end{array}$ & $\begin{array}{l}\text { Compilation } \\
\text { of successful } \\
\text { cases: } 12 \\
\text { companies } \\
\text { and } \\
\text { searching } \\
\text { centers. } \\
\text { modules, } \\
\text { Physic Cyber } \\
\text { System, } 4.0 \\
\text { Business map, } \\
4.0 \text { benefit }\end{array}$ \\
\hline $\begin{array}{l}\text { Dong and } \\
\text { Jong } \\
\text { (2017) }\end{array}$ & $\begin{array}{l}\text { Determinant } \\
\text { features in the } \\
\text { commercializa } \\
\text { tion } \\
\text { performance in } \\
\text { high } \\
\text { technology } \\
\text { companies }\end{array}$ & $\begin{array}{l}\text { It identified an } \\
\text { opportunity in } \\
\text { relation to } \\
\text { PYMES } \\
\text { performance } \\
\text { in the Korean } \\
\text { economic } \\
\text { industry }\end{array}$ & $\begin{array}{l}\text { Analysis of } \\
\text { social capital, } \\
\text { technological } \\
\text { performance } \\
\text { in the high } \\
\text { technology } \\
\text { absorption and } \\
\text { commercializa } \\
\text { tion capacity }\end{array}$ \\
\hline $\begin{array}{l}\text { Da Silva, } \\
\text { Kovaleski } \\
\text { and } \\
\text { Pagani } \\
(2018)\end{array}$ & 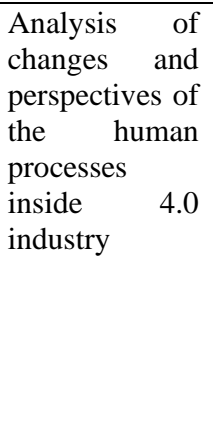 & $\begin{array}{l}\text { Acceleration } \\
\text { in the digital } \\
\text { process } \\
\text { between the } \\
\text { academy, } \\
\text { company and } \\
\text { government, } \\
\text { where all the } \\
\text { staff must } \\
\text { adapt to the } \\
\text { new technologies }\end{array}$ & $\begin{array}{l}\text { Systematic } \\
\text { review of } 50 \\
\text { articles }\end{array}$ \\
\hline
\end{tabular}

\begin{tabular}{|c|c|c|c|}
\hline $\begin{array}{l}\text { Gbadeges } \\
\text { hin } \\
(2018)\end{array}$ & $\begin{array}{l}\text { Analysis about } \\
\text { technical } \\
\text { aspects } \\
\text { validation, } \\
\text { market and } \\
\text { intellectual } \\
\text { property, with } \\
\text { the main goal } \\
\text { of decreasing } \\
\text { economic risks } \\
\text { and } \\
\text { uncertainty }\end{array}$ & $\begin{array}{l}\text { Acceleration } \\
\text { of high } \\
\text { technology } \\
\text { commercializa } \\
\text { tion through } \\
\text { minimal } \\
\text { investment in } \\
\text { technical and } \\
\text { commercial } \\
\text { validation }\end{array}$ & $\begin{array}{l}\text { New } \\
\text { theoretical } \\
\text { framework } \\
\text { named slim } \\
\text { marketing by } \\
\text { a crossed } \\
\text { study between } \\
16 \text { pharmacist } \\
\text { companies in } \\
\text { Finland }\end{array}$ \\
\hline $\begin{array}{l}\text { Hyunji, } \\
\text { Sun and } \\
\text { Won } \\
(2019)\end{array}$ & $\begin{array}{l}\text { Technological } \\
\text { performance } \\
\text { which is based } \\
\text { in I+D } \\
\text { performance in } \\
\text { patents and } \\
\text { selling growth } \\
\text { as well as } \\
\text { costs reduction }\end{array}$ & $\begin{array}{l}\text { It identified an } \\
\text { opportunity in } \\
\text { relation to } \\
\text { PYMES } \\
\text { performance } \\
\text { in the Korean } \\
\text { economic } \\
\text { industry }\end{array}$ & $\begin{array}{l}42,100 \\
\text { PYMES were } \\
\text { surveyed from } \\
2003 \text { to } 2014 \\
\text { with a } 23 \% \\
\text { result of } \\
\text { companies } \\
\text { belonging to } \\
\text { high } \\
\text { technology } \\
\text { industries }\end{array}$ \\
\hline $\begin{array}{l}\text { Wahyund } \\
\text { i, Rina } \\
\text { and Retno } \\
\text { (2019) }\end{array}$ & $\begin{array}{l}\text { Commercializa } \\
\text { tion and } \\
\text { transfer of } \\
\text { technology } \\
\text { acceleration } \\
\text { focused on } \\
\text { opened } \\
\text { innovation }\end{array}$ & $\begin{array}{l}\text { It helped to } \\
\text { compare the } \\
\text { efficiency of } \\
\text { commercializa } \\
\text { tion strategies, } \\
\text { discharge and } \\
\text { spin offs } \\
\text { creation }\end{array}$ & $\begin{array}{l}4 \text { universities } \\
\text { in Indonesia } \\
\text { that license } \\
\text { and } \\
\text { commercialize } \\
\text { their } \\
\text { technology } \\
\text { with } \\
\text { performance } \\
\text { indicators in } \\
\text { commercializa } \\
\text { tion strategies }\end{array}$ \\
\hline $\begin{array}{l}\text { Kim, } \\
\text { Sawng } \\
\text { and Park } \\
(2019)\end{array}$ & $\begin{array}{l}\text { Model of } \\
\text { commercializa } \\
\text { tion processes } \\
\text { validation of } \\
\text { digital } \\
\text { innovation in } 3 \\
\text { stages, } \\
\text { technology, } \\
\text { product and } \\
\text { market }\end{array}$ & $\begin{array}{l}\text { It identified } \\
\text { that most } \\
\text { advanced } \\
\text { countries } \\
\text { foment the } \\
\text { industrial } \\
\text { competitivene } \\
\text { ss through } \\
\text { opened } \\
\text { innovation }\end{array}$ & $\begin{array}{l}\text { Application of } \\
350 \text { surveys to } \\
\text { potential users } \\
\text { of the } 3 \text { stages }\end{array}$ \\
\hline $\begin{array}{l}\text { Yeverino } \\
\text { and } \\
\text { Montoro } \\
(2019)\end{array}$ & $\begin{array}{l}\text { Investigation } \\
\text { of efficiency } \\
\text { and } \\
\text { productivity of } \\
\text { academic units } \\
\text { in charge of } \\
\text { transfer of } \\
\text { technology in } \\
\text { Mexico }\end{array}$ & $\begin{array}{l}\text { It found } \\
\text { heterogeneity } \\
\text { in institutions } \\
\text { with limited } \\
\text { productivity } \\
\text { and income by } \\
\text { licenses with a } \\
40 \text { year delay } \\
\text { respect to } \\
\text { USA }\end{array}$ & $\begin{array}{l}2 \text { analysis } \\
\text { models to } 21 \\
\text { searching } \\
\text { centers and } \\
\text { higher } \\
\text { education } \\
\text { institutions }\end{array}$ \\
\hline
\end{tabular}

Table 1 Chart of referents about commercialization and transfer of technology methodology

Source: elaborated with proper information obtained from the cited authors

\section{Conclusions and recommendations}

The investigation found the need for the development of new strategies to strengthen an accelerate the commercialization and transfer of technology processes, due to the technological industry features such as the importance of time investment in validation stages, as well as verification that regulatory organisms demand and the incorporation in the market.

VILLAFAÑA-DÍAZ, Luis \& LEZAMA-DE LA ROSA, Miguel. Literature review on industry commercialization and transfer of technology 4.0. Journal of Technological Prototypes. 2020 
The analysis shows that the commercialization and transfer of technology channel has been boosted through the synergy between the triple helix, which is made of universities by means of generating research, the government through targeted innovation policies at tax incentives, as well as companies through investment in escalation and incorporation to the market.

Findings in this research describe the intellectual property importance as an opportunity in the commercial armor process, on the other hand, different models and systemic processes application of technical patent information to detect technological licensing opportunities, taking in mind that 4.0 industry shows a fast growth and it is considered as one of the main international markets. This investigation makes a contribution describing the different systematic tools and processes that are used in companies, governments and institutions in a 5 year period to commercialize and transfer knowledge and maximize the opportunities based on innovation inside 4.0 industry with changing and dynamic features.

Limitations when conducting research are related with the scarce concentrated investigation in the exploration of processes, as well as strategies for commercialization and transfer of technology, specifically in 4.0 industry, by consequence, it was identified an opportunity in this area of knowledge to develop new investigation. Consequently, later it will be developed a multifunctional tool based on strategic planning of a constant monitoring of technologies developed in universities through the technical study in patents to accelerate the commercialization and technological licensing process, which would improve the competitive business success.

\section{Interest conflict}

The authors declare that does not exist any interest conflict.

\section{References}

Da Silva, V., Kovaleski, J., \& Pagani, R. (2018). Technology Transfer and Human Capital in the Industrial 4.0 Scenario: A Theoretical Study. Future Studies Research Journal.
Dash, D., Farooq, R., Sankar, P., \& Sandhyavani, K. (2019). Internet of Things (IoT): The New Paradigm of HRM and Skill Development in the Fourth Industrial Revolution (Industry 4.0). The IUP Journal of Information Technology.

Dong, H., \& Jong, W. (2017). The Determinants of Technology

Commercialization Performance of Technology-based SMEs. Ksii Transactions On Internet And Information Systems.

Frey, C.B., \& Osborne, M.A. (2017). The Future of Employment: How susceptible are Jobs to computerisation? Technological Forecasting and Social Change, 2017, 114, C, 254., 114, 254.

Gbadegeshin, S. (2018). Lean Commercialization: A New Framework for Commercializing High Technologies. Technology Innovation Management Review.

Gbadegeshin, S. (2019). The Effect of Digitalization on the Commercialization Process of High-Technology Companies in the Life Sciences Industry. Technology Innovation Management Review.

Hayter, C., \& Link, A. (2018). Why Do Knowledge-Intensive Entrepreneurial Firms Publish Their Innovative Ideas? Academy of Management Perspectives.

Hecklau, F., Galeitzke, M., Flachs, S., \& Kohl, H. (2016). Holistic Approach for Human Resource Management in Industry 4.0. Procedia CIRP.

Hyunji, K., Sun, Y., \& Won, I. (2019). A Study on Technology Development Performance and Technology Commercialization Performance According to the Technology Development Capability of SMEs Focusing on a Comparative Analysis of Technology Business Groups. Open Innov Technol Mark.

INEGI(2020),https://www.inegi.org.mx/temas/ pecyt/default.html\#Informacion_general.

Jasiulewicz, K., Saniuk, A., \& Nowicki, T. (2017). The Maintenance Management in the Macro-Ergonomics Context. Advances in Intelligent Systems and Computing. 
Jun, S., Park, S., \& Jang, D. (2015). A Technology Valuation Model Using Quantitative Patent Analysis: A Case Study of Technology Transfer in Big Data Marketing. Emerging Markets Finance \& Trade.

Kauffman, M., \& Soares, M. (2018). Intellectual Property Law In The Fourth Industrial Revolution: Trade Secrets Risks And Opportunities. Revista Juridica Curitiba.

Khadhraoui, M., Plaisent, M., Lakhal, L., \& Prosper, B. (2016). Factors Inhibiting University-Industry Technology Transfer. Journal of IT and Economic Development.

Kim, M., Sawng, Y.-w., \& Park , S.-Y. (2019). Bridging the Gap in the Technology Commercialization Process: Using a ThreeStage Technology-Product-Market Model. Sustainability.

Kodama, F. (2018) Learning Mode and Strategic Concept for 4th Industrial Revolution. Journal of Open Innovation

Kovaleski, S., \& Pagani, N. (2018). Technology transfer in the supply chain oriented to industry 4.0: a literature review. Technology Analysis \& Strategic Managment.

Lalanda, P., Morand, D., \& Chollet, S. (2017). Autonomic Mediation Middleware for Smart Manufacturing. IEEE Internet Computing.

Maresova, P., Stemberkova, R., \& Fadeyi, O. (2019). Models, Processes, and Roles of Universities in Technology Transfer Management: A Systematic Review. Administrative Sciense.

Magruk, A. (2016). Uncertainty In The Sphere Of The Industry 4.0 - Potential Areas To Research. Business. Management and Education.

Mikulic, I. \& Stefanic, A. (2018) The Adoption of Modern Technology Specific to Industry 4.0 by Human Factor, 29TH DAAAM International Symposium on Intelligent Manufacturing and Automation, DOI: 10.2507/29th.daaam.proceedings.135
Misyunay, R., Mayhurova, D., \& Zubkov, A. (2018). La industria 4.0 la competencia entre nuevos modelos de negocios, la nueva esencia competitiva. Business Inform.

Nikolic, B., Ignjatic, J., Suzic, N., Stevanov, B., \& Rikalovic, A. (2017). Predictive Manufacturing Systems in Industry 4.0: Trends, Benefits And Challenges. Danube Adria Association Automation and Manufacturing.

OCDE (2015), OCDE Digital Economy Outlook 2015. OCDE. Paris: OCDE

OCDE(2020),https://data.oecd.org/searchresults $/ \mathrm{r}=\% 2 \mathrm{Bf} \% 2$ Ftype $\% 2$ Findicators $\& \mathrm{r}=\% 2 \mathrm{Bf} \% 2 \mathrm{~F}$ topics_en\%2Finnovation+and+technology

Park, S., Shin, W., \& Lee, Y. (2017). Building a new culture for quality management in the era of the Fourth Industrial Revolution. Total Quality Managment \& Business Excellence.

Savescu, D. (2017). The Importance Of Intellectual Property Protection In Technological Transfer. Some Aspects. Fiability \& Durability / Fiabilitate si Durabilitate.

UNCTAD (2019). Digital Economy Report 2019, Value Creation and Capture: Implications for Developing Countries, United Nations Publications. NY, USA

Wahyudi, S., Rina, W., \& Retno, T. (2019). Accelerating a Technology Commercialization; with a Discussion on the Relation between Technology Transfer Efficiency and Open Innovation. Open Innov Technol Mark.

Wank, A., Adolpha, S., Anokhinb, O., Arndtb, A., Anderlb, R., \& Metternich, J. (2016). Using a learning factory approach to transfer Industrie 4.0 approaches to small- and medium-sized enterprises. ELSEVIER.

Yeverino, J., \& Montoro, M. (2019). Efficiency and productivity in transfer units of scientific research results in Mexico. Contaduría y Administración. 